\title{
Estimating Canopy Structure of Douglas-fir forest stands from discrete-return LiDAR
}

Nicholas C. Coops ${ }^{1 *}$, Thomas Hilker ${ }^{1}$, Michael A. Wulder ${ }^{2}$, Benoît St-Onge ${ }^{3}$, Glenn Newnham ${ }^{4}$, Anders Siggins ${ }^{4}$, J. A. (Tony) Trofymow ${ }^{2}$

1-Department of Forest Resource Management, 2424 Main Mall. University of British Columbia, Vancouver. Canada. V6T 1 Z4

2-Canadian Forest Service (Pacific Forestry Centre), Natural Resources Canada, Victoria, British Columbia, Canada.

3-Department of Geography, Université of Québec in Montréal, Montréal, Québec, Canada.

4-CSIRO Forestry and Forest Products, Private Bag 10, Clayton South 3169, Victoria, Australia.

${ }^{*}$ Corresponding author:

Nicholas Coops

Phone: (604) 822 6452, Fax (604) 822-9106, Email: Nicholas.coops@ubc.ca

\section{Pre-print of published version.}

\section{Reference:}

Coops, N.C., Hilker, T., Wulder, M.A., St-Onge, B., Newnham, G., Siggins, A., Trofymow, J.A. 2007. Estimating canopy structure of Doulgas-fir forest stands from discrete-return LiDAR. Trees-Structure and Function. 21: 295-310

DOI:

doi:10.1007/s00468-006-0119-6

\section{Disclaimer:}

The PDF document is a copy of the final version of this manuscript that was subsequently accepted by the journal for publication. The paper has been through peer review, but it has not been subject to any additional copy-editing or journal specific formatting (so will look different from the final version of record, which may be accessed following the DOI above depending on your access situation). 


\section{ABSTRACT}

Variations in vertical and horizontal forest structure are often difficult to quantify as fieldbased methods are labour intensive and passive optical remote sensing techniques are limited in their capacity to distinguish structural changes occurring below the top of the canopy. In this study the capacity of small footprint $(0.19 \mathrm{~cm})$, discrete return, densely spaced ( 0.7 hits per $\left.\mathrm{m}^{-2}\right)$, multiple return, Light Detection and Ranging (LiDAR) technology, to measure foliage height and to estimate several stand and canopy structure attributes is investigated. The study focused on six Douglas-fir [Pseudotsuga menziesii spp. menziesii (Mirb.) Franco] and western hemlock [Tsuga heterophylla (Raf.) Sarg.] stands located on the east coast of Vancouver Island, British Columbia, Canada, with each stand representing a different structural stage of stand development for forests within this biogeoclimatic zone. Tree height, crown dimensions, cover, and vertical foliage distributions were measured in $20 \mathrm{~m} \times 20 \mathrm{~m}$ plots and correlated to the LiDAR data. Foliage profiles were then fitted, using the Weibull probability density function, to the field measured crown dimensions, vertical foliage density distributions and the LiDAR data at each plot. A modified canopy volume approach, based on methods developed for full waveform LiDAR observations, was developed and used to examine the vertical and horizontal variation in stand structure. Results indicate that measured stand attributes such as mean stand height, and basal area were significantly correlated with LiDAR estimates $\left(r^{2}=0.85, p<0.001\right.$, se $=1.8 \mathrm{~m}$ and $r^{2}=0.65, p<$ 0.05 , se $=14.8 \mathrm{~m}^{2} \mathrm{ha}^{-1}$ respectively). Significant relationships were also found between the LiDAR data and the field estimated vertical foliage profiles indicating that models of vertical foliage distribution may be robust and transferable between both field and LiDAR datasets. This study demonstrates that small footprint, discrete return, LiDAR observations can provide quantitative information on stand and tree height, as well as information on foliage profiles, which can be successfully modelled, providing detailed descriptions of canopy structure.

Key Words: Airborne LiDAR, Canopy structure, vertical foliage profiles, Weibull, Canopy volume profiles, remote sensing. 


\section{INTRODUCTION}

Understanding canopy structure is critical to provide insights into functional characteristics and processes of tree growth, and can reveal important information on the forests' response to disturbance at the individual tree, stand, community, and ecosystem level (Parker et al. 2004, Rhoads et al. 2004). The horizontal and vertical arrangement of forest canopies have been shown to strongly control the absorption of photosynthetically active radiation (PAR) and subsequently overall stand net primary productivity (Chason et al. 1991, Brokaw and Lent 1999, Chen et al. 2004, Hall et al. 2005). The pacific coastal temperate rainforests of Canada and the United States cover a significant area from Oregon to Alaska and are believed to play an important role in the global climate cycle (Parker et al. 2004). Within this region, the forests are dominated by Douglas-fir [Pseudotsuga menziesii spp. menziesii (Mirb.) Franco)] and western hemlock [Tsuga heterophylla (Raf.) Sarg] (Pojar and MacKinnon 1994, Harmon et al. 1986, Lefsky et al, 1999). The vertical canopies of these stands, particularly in later stages of development, show major structural complexity and are deemed to carry high biodiversity values, providing habitats for birds, mammals, and other fauna (Franklin et al. 2002, Mackinnon 2003, Van Pelt and Nadkarni 2004).

The two most often used variables to characterize the vertical and horizontal canopy structure are canopy closure and leaf area index (LAI). Canopy closure (or percent cover) can be defined as the fraction of the sky obscured by foliage within a crown (Lefsky et al. 1999) and often relies on visual canopy assessments (Whitney and Johnson 1984, Seischab et al. 1993). Whilst being a relatively fast technique, this method suffers from subjectivity and imprecision (Rhoads et al. 2004). LAl $\left(\mathrm{m}^{2} \mathrm{~m}^{-2}\right)$, is typically defined as the ratio of the single-sided surface area of leaves to the projected ground area (Barclay and Goodman 2000, Lefsky et al. 1999) and has proved useful in measuring the impacts of natural and anthropogenic disturbances on forest ecosystems (Rhoads et al. 2004). The direct measurement of LAl can involve destructive sampling of the canopy (Gower and Norman 1991), the use of litterfall traps, and the measurement of individual leaf area using planimeters (Rhoads et al. 2004). More commonly, indirect methods are applied, as they are nondestructive and rapid, and 
include systems that detect the relative penetration of solar radiation under the canopy such as the LI-COR LAI 2000 plant canopy analyzer (LI-COR Incorporated, Lincoln, Nebraska) and the TRAC LAl meter (Chen et al. 1997). However, in all of these cases, the LAl is merely the projected area of foliage on a horizontal plane, with no information on the vertical distribution of the leaf area through the canopy (Coops et al. 2004a). Less commonly used field-based methods to determine the distribution of both vertical and horizontal canopy elements include: the point-quadrat method (Warren-Wilson 1960, 1963, Aber, 1979a), which measures the interception of canopy elements in a series of vertical transects throughout the stand, and inventory-based foliar profiles estimated from measurements of crown dimensions and assuming a uniform foliage density within crown volumes (Walter and Hopkins 1990).

However, the use of detailed field-based techniques to quantify the horizontal and vertical distribution of elements in a canopy is an extremely labor intensive and expensive task especially if a large number of stands need to be measured (Hall et al. 2005). One of the major benefits of remote sensing technology is the ability to obtain spatially explicit data over large areas in a timely and economic fashion (Lim et al. 2003). Since the 1970's passive optical remote sensing imagery has been used to develop relationships, often empirical, between canopy indicators and spectral reflectance. However, this method is limited by the indirect relationships involved (Lim et al. 2003). In addition, the most commonly developed relationships (such as those between spectral band combinations and LAI, volume or total aboveground biomass) are nonlinear and saturate at approximately $100 \mathrm{Mg} \mathrm{ha}^{-1}$ (Cohen and Spies 1992) and an LAl greater than 3 (Lefsky et al. 1999). Likewise, synthetic aperture radar (SAR) has been found to be insensitive to differences in forest biomass above $150 \mathrm{Mg} \mathrm{ha}^{-1}$ (Waring et al. 1995) which is generally well below that observed in temperate forests.

As opposed to passive remote sensing approaches, Light Detection and Ranging (LiDAR) sensors directly measure the three-dimensional distribution of vegetation canopy components as well as sub-canopy topography, providing (a) high-resolution topographic elevation, and (b) highly accurate estimates of vegetation height, cover, 
and other aspects of canopy structure. LiDAR systems can be classified into either discrete return or waveform sampling systems. Full waveform sampling LiDAR systems compensate for a coarse spatial resolution $(10-100 \mathrm{~m})$ with a finer, and fully digitized, vertical resolution, providing full sub-meter vertical profiles; whilst discrete return LiDAR systems (with a footprint size of $0.1-2 \mathrm{~m}$ ) typically record only one to five returns per laser footprint (Lim et al. 2002) and are optimised for the derivation of sub-meter accuracy terrain surface heights (Blair et al. 1999, Schenk et al. 2001). Studies have demonstrated that the LiDAR measurement error for individual tree height (of a given species) is less than $1.0 \mathrm{~m}$ (Persson et al. 2002) and less than $0.5 \mathrm{~m}$ for plot based estimates of maximum and mean canopy height with full canopy closure (Næsset 1997, Magnussen and Boudewyn 1998, Magnussen et al. 1999, Næsset and Økland 2002, Næsset 2002). LiDAR estimates of height have been shown to be more consistent than manual, field based measurements (Næsset and Økland, 2002).

Full waveform sampling, large footprint LiDAR systems (such as the Scanning LiDAR Imager of Canopies by Echo Recovery (SLICER) and Laser Vegetation Imaging Sensor (LVIS) instruments (Harding et al. 2001, Blair et al. 1999) show promise for mapping of forest structure, as all laser energy reflected by the many surfaces of the geometrically complex crowns are recorded by the instrument (Lefsky et al. 2005). Large footprint waveform recording LiDAR systems are not currently available commercially. In contrast, small footprint discrete return LiDAR systems are widely available. Further, the number of returns recorded per emitted small footprint return is increasing with new sensor developments, offering increasingly detailed structural information. For this study, it is hypothesized that emulation of waveform return type information with small footprint discrete return LiDAR data will produce analogous information, thereby enabling the extension of this established approach to the widely available small footprint LiDAR systems. 
This study reports results on the application of discrete small-footprint LiDAR to estimate vertical and horizontal canopy attributes of Douglas-fir/western hemlock forest stands on the east coast of Vancouver Island, British Columbia, Canada. This study had two objectives:

- Determine, from a suite of plot based field measurements, how well vertical and horizontal canopy structure can be modelled and characterised for a sample of stands spanning a range of forest architectures; and

- Explore the capacity of small-footprint, discrete return, LiDAR to estimate vertical and horizontal canopy structure for the same sample of stands.

\section{METHODOLOGY}

\subsection{Study Area}

The study area is located in Douglas-fir and western hemlock dominated forests within the Oyster River area found between Courtenay and Campbell River on the leeward eastern side of Vancouver Island, British Columbia, Canada. The study covers a $5 \mathrm{~km} \mathrm{x}$ $5 \mathrm{~km}$ area (UTM Zone 10, NAD83: Upper left 331150E, 5529900N; Lower right $336150 \mathrm{E}, 5524900 \mathrm{~N}$ ) within the dry maritime Coastal Western Hemlock biogeoclimatic subzone (CWHxm) with an average annual precipitation of $1500 \mathrm{~mm}$ and mean annual temperature of $9.1^{\circ} \mathrm{C}$ (Pojar et al. 1991). This subzone has a maritime climate with typically cool summers and mild winters, though can experience significant dry conditions during the summer. The study area spans the transition from the Nanaimo Lowlands and Leeward Island Mountain Ecosections (Demarchi 1996), ranging in elevation from $120 \mathrm{~m}$ to $460 \mathrm{~m}$, and is within 10 to $15 \mathrm{~km}$ of the coast. Douglas-fir is the dominant tree species on dry to mesic site series, though wetter site series will contain western hemlock and western red-cedar [Thuja plicata (Donn.)] (Green and Klinka 1994). Forests within the area are predominantly second-growth, arising after harvest and slash-burning of the original forest present from 1920 to 1950. Much of the area did not regenerate naturally (Goodwin 1937) and, as a result, some of the area was planted starting in the late1940's with second growth harvesting and subsequent planting beginning in 1989. 
Publicly available, digital 1:20 000 scale, geospatial data relating to topography, roads, water bodies and cadastral boundaries were obtained for use in orienting and locating stands within the area. In addition forest inventory data (derived from 1996 aerial photography, updated in 1999) was made available by local forest managers which provided information on the dominant and co-dominant species, site index class, and year of stand establishment. Historical information on regeneration and fire were also available (Goodwin 1937, Taylor 2002). High spatial resolution imagery from the Quickbird satellite (0.68 cm panchromatic; $2.5 \mathrm{~m}$ multi-spectral) was also acquired over the region on August $4^{\text {th }}, 2004$.

\subsection{Field Plot Selection and Inventory Measurements}

Using a combination of the high spatial resolution satellite imagery, and the compiled forest inventory data, a number of forest stands were selected covering a range of species composition, age classes, and site indices within an area of 2500 ha. Various stands were visited by a field crew and six stands were chosen covering the range of Douglas-fir structural stage conditions (Table 1). Within each stand, a $20 \times 20 \mathrm{~m}$ square plot was positioned and the central point located using differentially corrected GPS (GeoXT, Trimble, Sunnyvale, California) with a positional accuracy of less than $2 \mathrm{~m}$. All trees with a diameter at breast height $(\mathrm{DBH})$ of more than $10 \mathrm{~cm}$ were measured and tree species recorded. For each tree maximum height, base to live crown, maximum and minimum radius of crown, and individual crown density (as a percent) were determined. All height characteristics were measured and tree stem locations mapped to a local coordinate system using a Laser Hypsometer and a compass registered to the respective plot centre peg. Maximum plot height was derived as the maximum individual tree height measured within the plot and mean height describes the arithmetic mean height of all measured trees in the plot. Plot I is a highly stocked, even aged, stand, dominated by Douglas fir, containing a small number of western red cedar that naturally established in 1932 and likely subject to significant regeneration delay. Plot II is a red alder dominated stand, with a small component of older Douglas fir and western red cedar trees and is relatively open and structured, in a wet location close to a creek. Plot III is a mixed mature red alder and Douglas fir stand, relatively open and even in 
structure, again in a wet location close to a creek. Plot IV is a relatively dry, mixed Douglas fir, hemlock stand, even aged and well structured with a dense understorey. Plot $\mathrm{V}$ is an even-aged, mature, near pure stand, dominated by Douglas fir with small amounts of western red cedar, western hemlock, and a single red alder. Plot IV is a mature stand dominated by Douglas fir and hemlock with single red alder, western red cedar stems located on steep terrain near the Oyster River.

Table 1: Summary of site locations, stand history, and field measurements of plot characteristics

\begin{tabular}{|c|c|c|c|c|c|c|}
\hline Stand Number & $\bar{I}$ & II & III & IV & $\overline{\mathbf{V}}$ & $\mathbf{V I}$ \\
\hline & 33457 & 33590 & 33279 & 33563 & 33209 & 33285 \\
\hline \multirow[t]{2}{*}{ Easting $(\mathrm{m})$} & 0 & 6 & 7 & 3 & 6 & 1 \\
\hline & 55275 & 55286 & 55292 & 55271 & 55267 & 55250 \\
\hline Northing $(m)$ & 00 & 17 & 56 & 52 & 43 & 28 \\
\hline Shapefile plot number & L1 & L3 & L4 & L11 & L2 & L5 \\
\hline Site Index ${ }^{1}(\mathrm{~m})$ & 28 & $\mathrm{n} / \mathrm{a}$ & 23 & 36 & 29 & 28 \\
\hline First Harvest ${ }^{2}$ & 1928 & 1929 & $\mathrm{n} / \mathrm{a}$ & 1943 & 1931 & 1929 \\
\hline Last Fire & 1930 & 1938 & 1939 & 1939 & 1934 & 1930 \\
\hline $\begin{array}{l}\text { Silvicultural Treatment if } \\
\text { known }^{3}\end{array}$ & $\mathrm{n} / \mathrm{a}$ & $\mathrm{n} / \mathrm{a}$ & $P$ & PF & $\mathrm{P}$ & $\mathrm{n} / \mathrm{a}$ \\
\hline Mean height of stand $(\mathrm{m})$ & 18.98 & 18.23 & 22.1 & 27.7 & 23.7 & 28.7 \\
\hline $\begin{array}{l}\text { Standard deviation of } \\
\text { height }(m)\end{array}$ & 4.01 & 8.2 & 9.4 & 5.9 & 7.0 & 9.2 \\
\hline Maximum height $(\mathrm{m})$ & 24.2 & 36.5 & 32.6 & 40.6 & 38.5 & 33.5 \\
\hline Total number of trees/ha & 1325 & 1000 & 700 & 556 & 575 & 800 \\
\hline
\end{tabular}




\begin{tabular}{|c|c|c|c|c|c|c|}
\hline$\left(\mathrm{ha}^{-1}\right)$ & & & & & & \\
\hline Total Basal area $\left(\mathrm{m}^{2} \mathrm{ha}^{-1}\right)$ & 49.25 & 33.93 & 46.4 & 79.3 & 38.8 & 48.96 \\
\hline$\%$ BA Douglas-fir & 80.81 & 39.64 & 14.81 & 81.90 & 80.40 & 92.76 \\
\hline$\%$ BA red alder & 0 & 58.64 & 85.19 & 0 & 9.96 & 7.24 \\
\hline$\%$ BA western redcedar & 19.19 & 0 & 0 & 18.10 & 9.64 & 0 \\
\hline$\%$ BA western hemlock & 0 & 1.72 & 0 & 0 & 0 & 0 \\
\hline Mean DBH $(\mathrm{cm})$ & 20.6 & 21.4 & 27.7 & 30.8 & 27.7 & 26.4 \\
\hline $\begin{array}{l}\text { Average canopy major axis } \\
\text { (m) }\end{array}$ & 4.5 & 7.1 & 7.6 & 5.5 & 5.4 & 6.9 \\
\hline $\begin{array}{l}\text { Average canopy minor axis } \\
\text { (m) }\end{array}$ & 3.3 & 6.1 & 6.2 & 4.6 & 4.4 & 5.1 \\
\hline $\begin{array}{l}\text { Apparent LAI as estimated } \\
\text { from point quadrat method } \\
\left(\mathrm{m}^{2} \mathrm{~m}^{-2}\right)\end{array}$ & 2.3 & 3.0 & 4.2 & 2.7 & 3.1 & 3.0 \\
\hline Mean Crown Density (\%) & 89.6 & 95.6 & 98.5 & 93.3 & 94.8 & 94.8 \\
\hline
\end{tabular}

- $\quad$ Footnote 1: n/a indicates stand type shown as swamp in inventory with no site index. SI is height of Douglas fir in 50 years breast height age. Stand age may be 10 years older than breast height age.

- $\quad$ Footnote 2: $\mathrm{n} / \mathrm{a}$ indicates stand was not harvested and originally shown as alder swamp in 1937

- Footnote 3: P indicates stand was planted, and F that the stand was fertilized in 1994 with $200 \mathrm{~kg}$ Urea N/ha

\subsection{Field Based Measures of Canopy Structure}

For this research, two field-based methods were used to estimate the vertical and horizontal canopy structure of each stand; the point quadrat and the inventory-based foliar profile method. In the first method, the vertical distribution of material within the canopy was measured by means of a foliage height profile (MacArthur and Horn 1969) using the camera point-quadrat method developed by Aber (1979a). This point-quadrat sampling method was first described by Warren Wilson $(1960,1963)$ who utilized a series of vertical transects from the top to the bottom of the canopy. Along each vertical 
transect the height of each intersecting leaf is recorded. Equations are then applied to compute total canopy apparent LAI, in addition to vertical foliage density profiles and average leaf inclination angles. An optical point-quadrat method for forest canopies was developed by MacArthur and Horn (1963) using a 35-mm camera with a telephoto lens, calibrated for distance measurement, with a superimposed $3 \times 5$ square grid marked on the camera focal plane. The technique was applied by Aber (1979a, 1979b) to a range of northern temperate forest canopies. By assuming a random horizontal distribution of foliage, data on the lowest leaf can be transformed (MacArthur and Horn 1969) into estimates of total apparent LAl of the canopy. However, when the foliage is clustered and foliage density is high, the method underestimates total LAl as demonstrated by Aber (1979a, 1979b) and more recently, by Radtke and Bolstad (2001). However, as underestimation is constant at all canopy levels, relative leaf area profiles can be developed that accurately represent the fraction of leaf area in each canopy layer (Smith and Martin 2001, Coops et al. 2004a). At the centre, and eight equally spaced points along the edge of a plot $(n=9)$, the camera was mounted on a $1 \mathrm{~m}$ tall tripod, directed upward towards the canopy and levelled. At each of the 9 locations, 15 grid squares were sampled, resulting in 135 observations per plot. Within the centre of each grid square the distance to the intersecting canopy element (e.g. leaf, branch, stem, etc.) was determined by focussing the focal plane of the camera on the element and reading the distance. The tree species was also identified and recorded. The equations presented in Aber (1979b) were then applied to estimate total site vegetation area index (including the influences of leaves, branches, and stems). As the MacArthur and Horn technique is based on the recording of visual observations of height and species by the camera operator, the time of day should have no influence on the estimates. By contrast, there are significant problems associated with variations in ambient light conditions in the analysis of hemispherical photography, particularly the penumbral effect caused by the direct beam. However, The MacArthur and Horn technique does suffer from a significant drawback with respect to low precision in height estimation for the uppermost intersections of the canopy. 
In the second method, inventory-based stand level foliage density profiles are determined using measurements of tree density, height distribution, crown size and shape in a sample plot. A 'theoretical' foliage profile $(F P)$ can then be derived (Walker and Hopkins 1990, Ni-Meister et al. 2001) when these data are used in the model (written here for a single dominant stratum)

$$
F P(z)=\lambda \bar{A} F \int_{h 1}^{h 2} p(h) S(h, T, z) d h
$$

where $\lambda$ is the number density of trees, $\bar{A}$ is the mean vertically projected crown area, $F$ is the within-crown foliage area density (assumed to be uniform within crown volumes), $p$ is the distribution function for tree heights, $h$ is the tree height, $S$ is a geometric factor related to crown shape, and $T$ is the crown depth (height from first branch to the top of the tree). An estimate of $F$ can be made for each crown based on the observed crown density if the leaf angle distribution is assumed or measured while the geometric factor $S$ is the relative cross-sectional area of a slice of the crown as a function of height $z$. All tree crowns were assumed to be ellipsoidal with the factor $S$ taking the form

$$
S(h, T, z)=1-\frac{\left[z-(h-T / 2]^{2}\right.}{(T / 2)^{2}}
$$

\subsection{LiDAR Data Acquisition}

Scanning laser data were acquired June 8, 2004, using the Terra Remote Sensing's (Sidney, British Columbia, Canada) LiDAR instrument on a Bell 206 Jet Ranger helicopter. Based on the pulse frequency, lowest sustainable flight speed and altitude, ground point sampling densities of 0.7 per $\mathrm{m}^{2}$ were achieved with a beam footprint (ground spot size) of $0.19 \mathrm{~m}$ diameter. Separation of ground versus non-ground (canopy) hits was carried out using Terrascan v4.006 (Terrasolid, Helsinki, Finland) which employs iterative algorithms that combine filtering and thresholding methods (Kraus and Pfeifer 1998, Axelsson 1999) and classify the LiDAR data into either ground or non-ground returns. Secondly, a $1 \mathrm{~m}$ gridded Digital Elevation Model (DEM) was developed from all LiDAR ground hits using GIS-based DEM generation software (Arc/Info, TOPOGRID), based on the ANUDEM program (Hutchinson 1989). All available ground classified LiDAR hits were used in the DEM development on the 
assumption that the Terrascan classification is correct. Finally, all non-ground LiDAR hits were then subtracted from the topographic surface to produce estimates of vegetation height.

\subsection{Height Derivation from Small-Footprint LiDAR:}

In this study the approach of Lovell et al. (2003) was followed resulting in the computation of forest stand attributes over a $20 \times 20$ m window centred over the plot location. Maximum height was calculated as the highest return within the window size. Dominant height was calculated using spatial stratification and dividing each plot into a smaller grid to obtain $\mathrm{N}$ areas within which the highest point is found. These $\mathrm{N}$ heights are then averaged to obtain a stratified dominant height estimate. In this case, the plot was divided into four sub-plots and the highest return in each sub-plot was averaged to obtain a dominant height estimate for the plot (Næsset 1997, Lovell et al. 2003).

\subsection{LiDAR Based Measures of Canopy Structure}

First and last LiDAR hits can also be used to construct an estimate of the projected foliage density profile. However, owing to the inability of the vertical view to resolve foliage angle distribution, clumping and non-foliage elements, the profiles derived are not the same as the true foliage density profiles and the derived profiles are referred to here as "apparent" foliage profiles (AFP). The difference between the true and apparent profiles depends on the canopy structure and type as discussed by Ni-Meister et al. (2001), since this effects the nature of its projection in the vertical direction.

Derivation of the apparent foliage profile from LiDAR observations has been well described (Lovell et al. 2003, Riano et al. 2003). The probability of a gap from the top of the canopy to a given height, $z$, can be estimated by summing the total number of hits down to $z$ and comparing them to the total number of independent LiDAR shot $(N)$ :

$$
P_{\text {gap }}(z)=1-\frac{\left\{\# z_{j} \mid z_{j}>z\right\}}{N}
$$


where $\mathrm{Az}$ is the number of hits down to a height $z$ above the ground. The cumulative projected foliage area index from the top of the canopy down to a height $z$ is then given by,

$$
L(z)=-\log \left(P_{\text {gap }}(z)\right)
$$

where the first derivative of $L(z)$ is the apparent foliage density profile (Lovell et al. 2003).

Fitting the Weibull Distribution to Foliage Profiles

Several different distributions can be fitted to the foliage density profile in order to stabilize the distribution with respect to rapid changes in $\mathrm{P}_{\text {gap }}$ and to provide a convenient summary of the vertical form. The most commonly applied distribution is a Weibull function, due to its flexibility in characterizing foliage distributions of various species (Vose 1988, Gillespie et al. 1994, Kershaw and Maguire 1995, Xu and Harrington 1998, Lovell et al. 2003). This distribution has also been used (Magnussen et al. 1999) to examine the distribution of canopy heights from airborne LiDAR systems by comparing the probability of LiDAR height quantiles above a desired height with the distribution of leaf area. The Weibull cumulative density function can be related to the cumulative projected foliage area index as follows,

$$
L(z)=1-\left[e^{-\left(\frac{1-z / H}{\alpha}\right)^{\beta}}\right]
$$

where $\alpha$ and $\beta$ are fitted parameters and $H$ is the maximum canopy height. The height parameter may either be fitted or set to the height of the highest return. The apparent foliage profile can then be calculated as an exact derivative (Lovell et al. 2003). As discussed by Bailey and Dell (1973) and Xu and Harrington (1998), the a parameter provides a vertical scaling and positioning factor for movement of the distribution and the $\beta$ provides the capacity to increase or decrease the breadth of the distribution (Figure 1). 

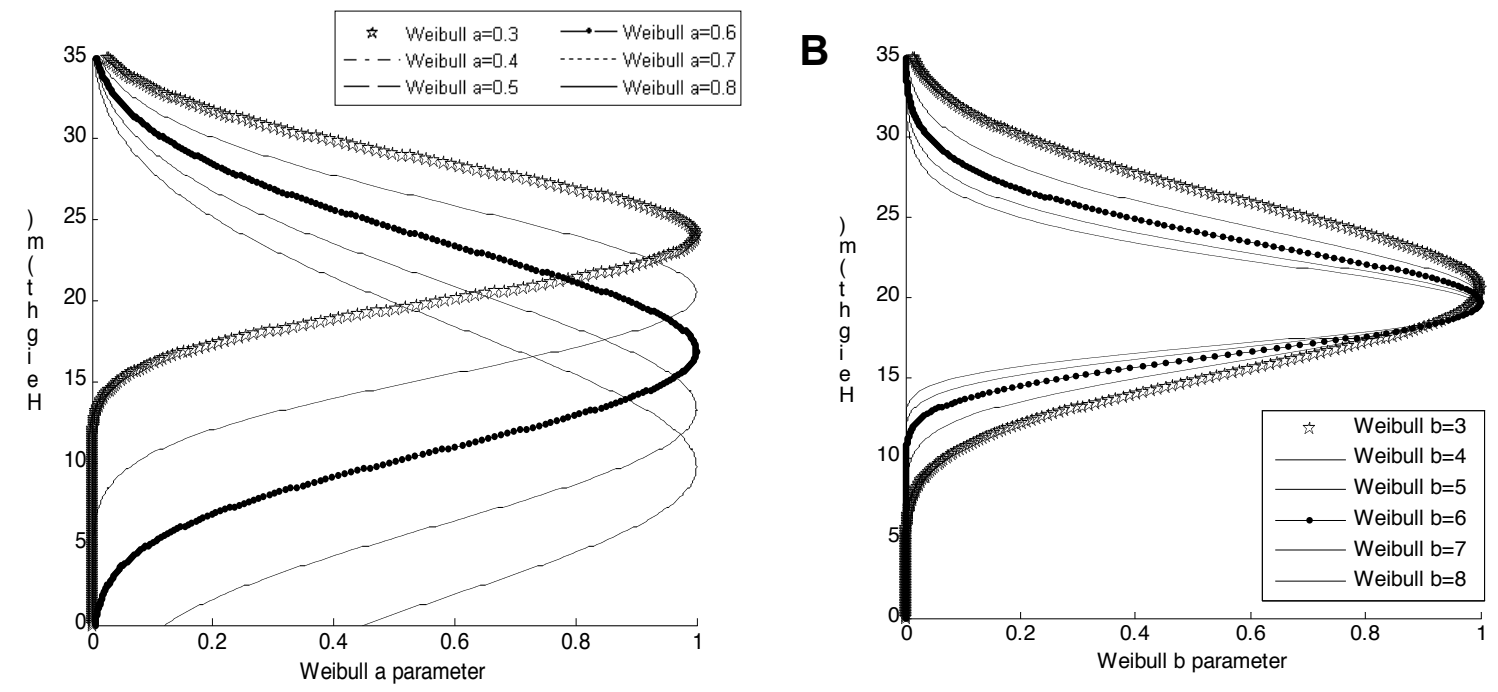

Figure 1: Effect of variation of the $\alpha$ and $\beta$ parameter in a Weibull distribution with (a) variation in $\alpha$ providing a scaling and positioning factor for movement of the distribution and (b) variation in $B$ allowing for an increase or decrease the breadth of the distribution.

Comparison of LiDAR and Field-Based Measured Tree Heights and Apparent Foliage Profiles

Canopy heights from the six plots were first compared to the LiDAR returns within a 20 $x 20 \mathrm{~m}$ window centred over the plot location. Based on the previous supporting studies (Lim et al. 2003, Næsset et al. 2004), a strong relationship between the field measured maximum tree heights and the LiDAR maximum height was expected.

In order to test the utility and transferability of the Weibull distribution to model foliage profiles, the Weibull distributions were fit to the cumulative LAI data $L(z)$ derived from both the point-quadrat and forest inventory measurements. The Weibull distribution parameters $a$ and $b$ derived from both of the field based foliage density profiling techniques were first compared to a range of field-measured stand attributes including the size and height of tree crowns in order to develop an understanding of the relationship between field measures and the Weibull distribution parameters. Following this assessment, the Weibull distribution was fitted to the LiDAR returns extracted from a $20 \times 20 \mathrm{~m}$ window centred on the field data plots. Whilst the number of hits within the 
canopy using the optical point-quadrat method and the LiDAR observed returns will be different, it was anticipated that the Weibull fitted parameters derived from each profile should be highly correlated.

\subsection{LiDAR Canopy Volume Profiles}

Another method developed to assess and model canopy structure using LiDAR data is the examination of filled and open volumes within a forest canopy. Using full waveform data, Lefsky et al. (1999) developed a technique to examine and model three dimensional canopy structure, termed canopy volume profiles. The method superimposed a matrix over the forest canopy composed of $10 \mathrm{~m} \times 10 \mathrm{~m}$ square and 1 $\mathrm{m}$ tall cells or voxels up to the level of the highest return. These cells are classified in two steps. First, each cell is classified as either "filled" or "empty" volume depending on

whether a return originated from that point in the canopy. Second, filled cells are labeled either "euphotic" zone, if the cell is located within the uppermost $65 \%$ of all filled volumes, or "oligophotic" zone if it is located below this point in the profile. As discussed by Lefsky et al. (1999) the terms "euphotic" and "oligophotic" were proposed by Richards (1983), to refer to the zone in the canopy which intercepts the bulk of available light (euphotic) and the zone beneath it. The $65 \%$ threshold value is derived from a theoretical expectation for the fraction of energy returned from the first unit of LAI, assuming an extinction coefficient of 1 (Lefsky et al 1999). This effectively provides a broad classification of the canopy into active and less active photosynthetic zones. Empty volumes are then divided into closed gap or open gap depending on whether they occur above of below the upper most filled volume. The result is four classes; euphotic filled, oligophotic filled, closed gap and open gap

Lefsky et al. (1999) estimated canopy volume profiles from full waveform SLICER data, rather than small footprint, discrete return, LiDAR data and used each canopy volume profile class as an independent variable in multivariate linear regression to relate the profiles to plot-estimated biomass and other structural attributes. In this research, we modify the Lefsky et al. (1999) computations of canopy volume profile to allow their prediction from discrete (first and last return) LiDAR data. To enable this, each of the 
$20 \mathrm{~m} \times 20 \mathrm{~m}$ plots were subset into sixteen $5 \mathrm{~m} \times 5 \mathrm{~m}$ windows and all LiDAR non-ground returns binned within of these $25 \mathrm{~m}^{2}(5 \times 5)$ plot subsets The number of returns within each of the sub-plots at $1 \mathrm{~m}$ height intervals were then counted and corrected according to Lefsky et al. (1998) and Riano et al. (2003). A sub plot size of $25 \mathrm{~m}^{2}$ is a compromise between obtaining a sufficient number of ground returns required for the correction of small footprint LiDAR returns, and having enough subplots within the area to characterize the stand. The volume elements of the canopy were then classified as either closed gap (when no hit occurred within that volume element), oligophotic crown zone (when a hit occurred within the volume element that was within the lower $35 \%$ of the canopy height for this subplot), or euphotic (for volumes that contained hits that were within the uppermost $65 \%$ of the canopy height for this subplot ). All volume elements that were located above the uppermost LiDAR hit were classified as "open gap." The crown volumes class per plot were finally computed by summing the number of occurrences of each volume class over all 16 subplots at each height. The canopy volume profile volume classes were then compared to the stand structural attributes including crown volume, stem density and basal area. In addition correlations were compared with variables used by Lefsky et al. (1999) who utilised the same technique in similar forest types in the state of Washington., USA.

\section{RESULTS}

\subsection{Plot Tree Heights}

Mean and maximum tree height, calculated from the small footprint, discrete return, LiDAR observations within a $20 \times 20 \mathrm{~m}$ window centred over each plot location (Table 2 ), were highly correlated with field measured heights (mean plot height: $r^{2}=0.85, p<$ 0.001 , se $=1.8 \mathrm{~m}$; or maximum height $\mathrm{r}^{2}=0.82, p<0.05$, se $=2.2 \mathrm{~m}$ (Figure 2)). However, the LIDAR estimates of plot mean tree height were consistently lower than field height with the degree of demonstrated bias increasing with stand height. No bias was evident in the LIDAR data for maximum tree heights. 


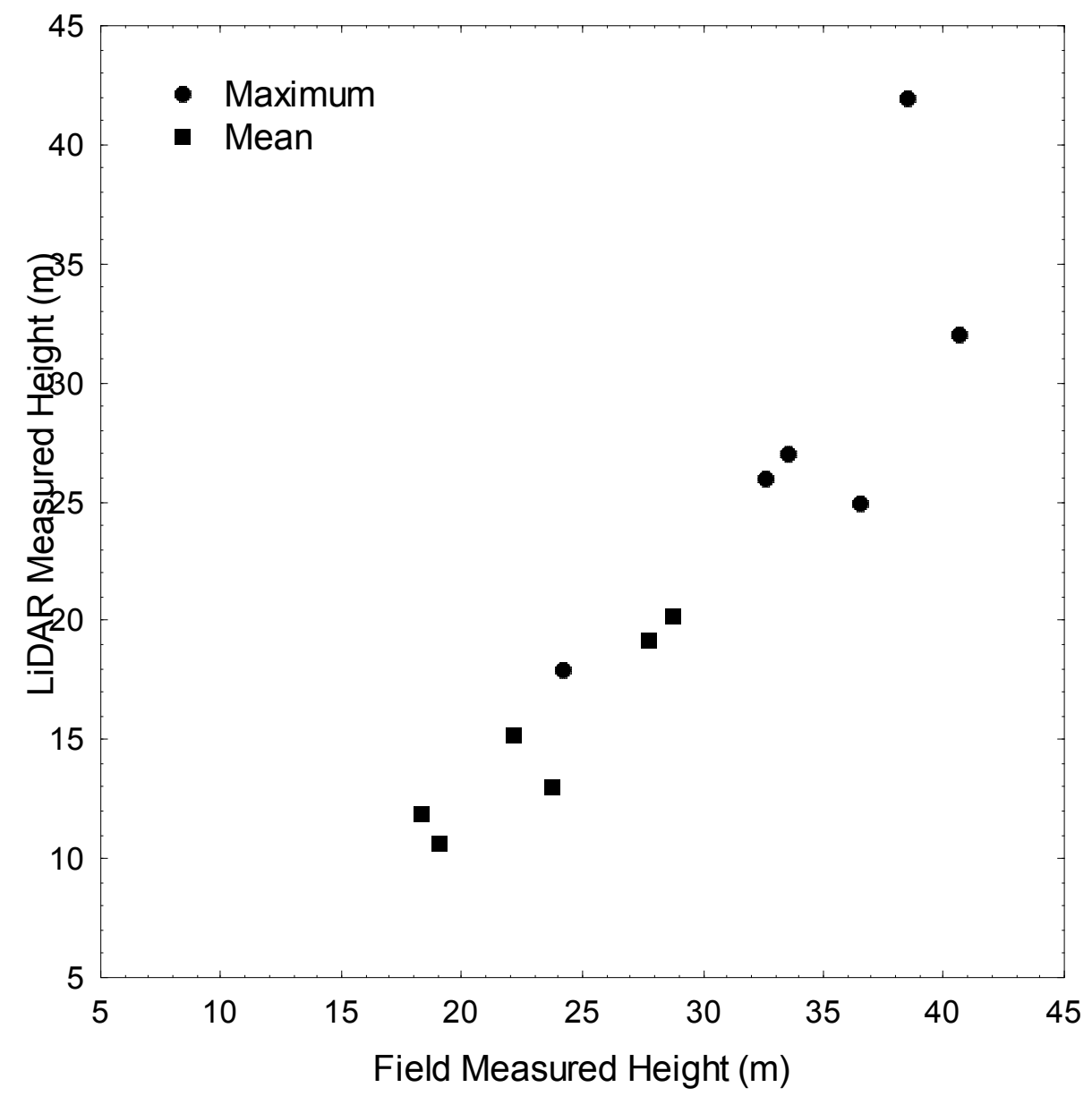

Figure 2: Relationship between (a) mean and (b) maximum plot tree height derived from the small footprint, discrete return, LiDAR observations and those measured in the field (mean plot height: $r^{2}=0.85, p<0.001$, se $=1.8 \mathrm{~m}$; or maximum height $r^{2}=0.82, p<0.05$, standard error $=2.2 \mathrm{~m}$ ).

Table 2: Weibull distribution parameters, canopy volume profile estimates, plot tree heights from the point quadrat, inventory, and LiDAR observations for the six architectural types.

\begin{tabular}{lllllll}
\hline Stand Number & I & II & III & IV & V & VI
\end{tabular}

$\begin{array}{lllllll}\text { Inventory Weibull a } & 0.71 & 0.73 & 0.67 & 0.67 & 0.60 & 0.59 \\ \text { Inventory Weibull ß } & 7.47 & 5.71 & 3.56 & 5.8 & 4.67 & 2.1 \\ \text { Point quadrat } & 0.73 & 0.71 & 0.61 & 0.56 & 0.64 & 0.54\end{array}$




\begin{tabular}{|c|c|c|c|c|c|c|}
\hline Weibull $\alpha$ & & & & & & \\
\hline $\begin{array}{l}\text { Point quadrat } \\
\text { Weibull } B\end{array}$ & 7.51 & 6.99 & 5.66 & 4.87 & 4.91 & 5.65 \\
\hline LiDAR Weibull $\alpha$ & 0.56 & 0.67 & 0.53 & 0.41 & 0.52 & 0.40 \\
\hline LiDAR Weibull ß & 4.80 & 5.66 & 3.71 & 2.61 & 2.48 & 2.97 \\
\hline Open Gap Volume & 6.2 & 12.0 & 12.4 & 5.8 & 9.3 & 4.9 \\
\hline Closed Gap Volume & 6.5 & 8.0 & 10.5 & 13.6 & 8.9 & 17.0 \\
\hline $\begin{array}{l}\text { Oligophotic Zone } \\
\text { Volume }\end{array}$ & 10.1 & 6.2 & 6.3 & 13.8 & 13.4 & 8.4 \\
\hline $\begin{array}{l}\text { Euphotic } \\
\text { Volume }\end{array}$ & 6.2 & 5.8 & 4.8 & 6.8 & 8.4 & 4.7 \\
\hline $\begin{array}{l}\text { Filled Canopy } \\
\text { Volume }\end{array}$ & 16.3 & 12.0 & 11.0 & 20.6 & 21.8 & 13.1 \\
\hline Filled and Closed & & & & & & \\
\hline Gap & 22.8 & 20.0 & 21.6 & 34.2 & 30.7 & 30.1 \\
\hline Canopy Volume & & & & & & \\
\hline $\begin{array}{l}\text { Filled/ Filled+Closed } \\
\text { Gap }\end{array}$ & 0.71 & 0.60 & 0.51 & 0.60 & 0.71 & 0.43 \\
\hline Mean height (field) & 18.98 & 18.23 & 22.1 & 27.7 & 28.7 & 23.7 \\
\hline $\begin{array}{l}\text { Mean } \\
\text { (LiDAR) }\end{array}$ & 13.8 & 15.6 & 17.6 & 22.7 & 20.3 & 18.6 \\
\hline Max height (field) & 24.3 & 36.5 & 32.6 & 38.5 & 40.6 & 33.5 \\
\hline Max height (LiDAR) & 28.4 & 33.2 & 33 & 35.2 & 35.2 & 35.7 \\
\hline
\end{tabular}




\subsection{Foliar Profile Distribution Parameters and Crown and Stand Attributes}

Given the variation of the Weibull distribution functions (Figure 1), it was expected that crown dimensions should be correlated with the Weibull $\alpha$ and $\beta$ parameter values. Variations in the point quadrat estimates of the Weibull a parameter were found to match changes in the mid-crown depth (Figure 3a) while the Weibull $\beta$ was related to average plot crown length (Figure $3 b$ ). In both cases, the relationship was significant ( $p$ $<0.05$ level with $r^{2} \geq 0.72$ ) and in a negative direction indicating increasing Weibull parameters are associated with relatively lower and broader crown shapes. The Weibull $\beta$ parameter was also significantly correlated $(p<0.05)$ to other attributes such as mean tree DBH (Figure $3 c)\left(r^{2}=0.92\right)$, and stand density $\left(r^{2}=0.94\right)$ (Figure $\left.3 d\right)$.

(A)

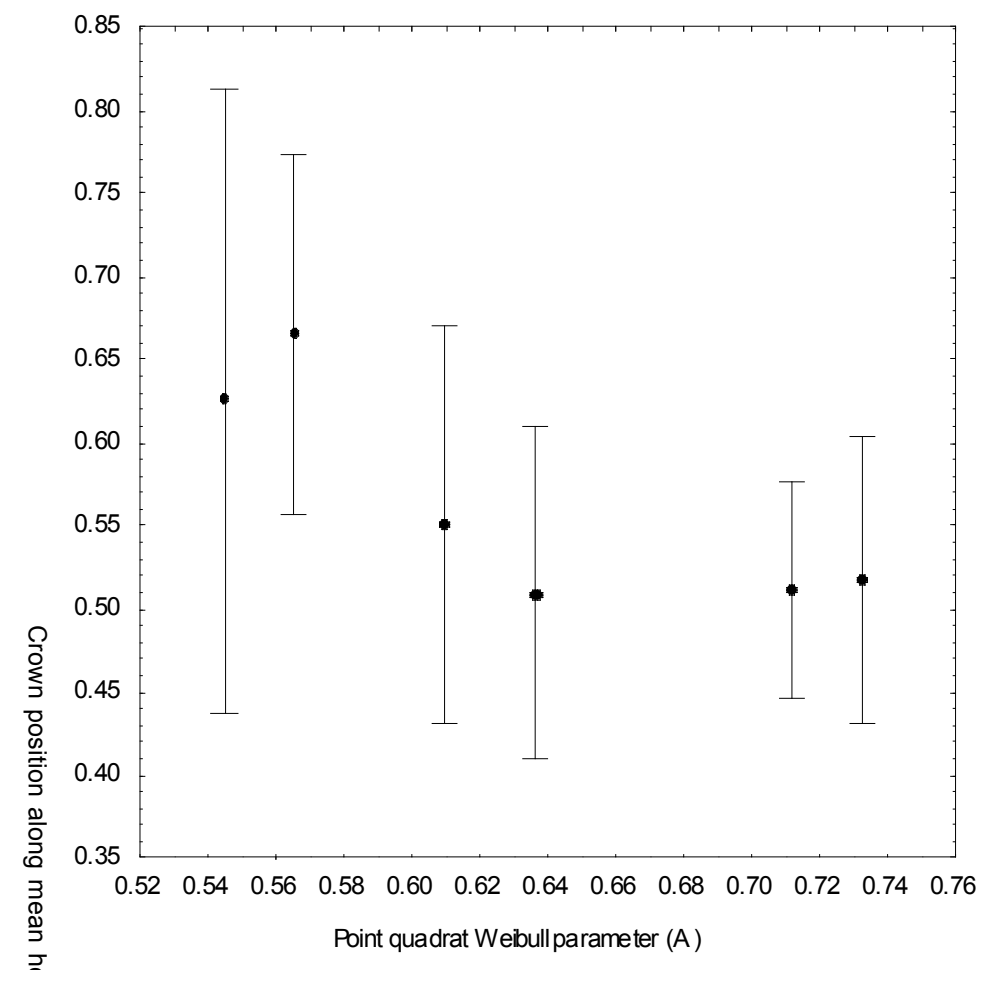


(B)

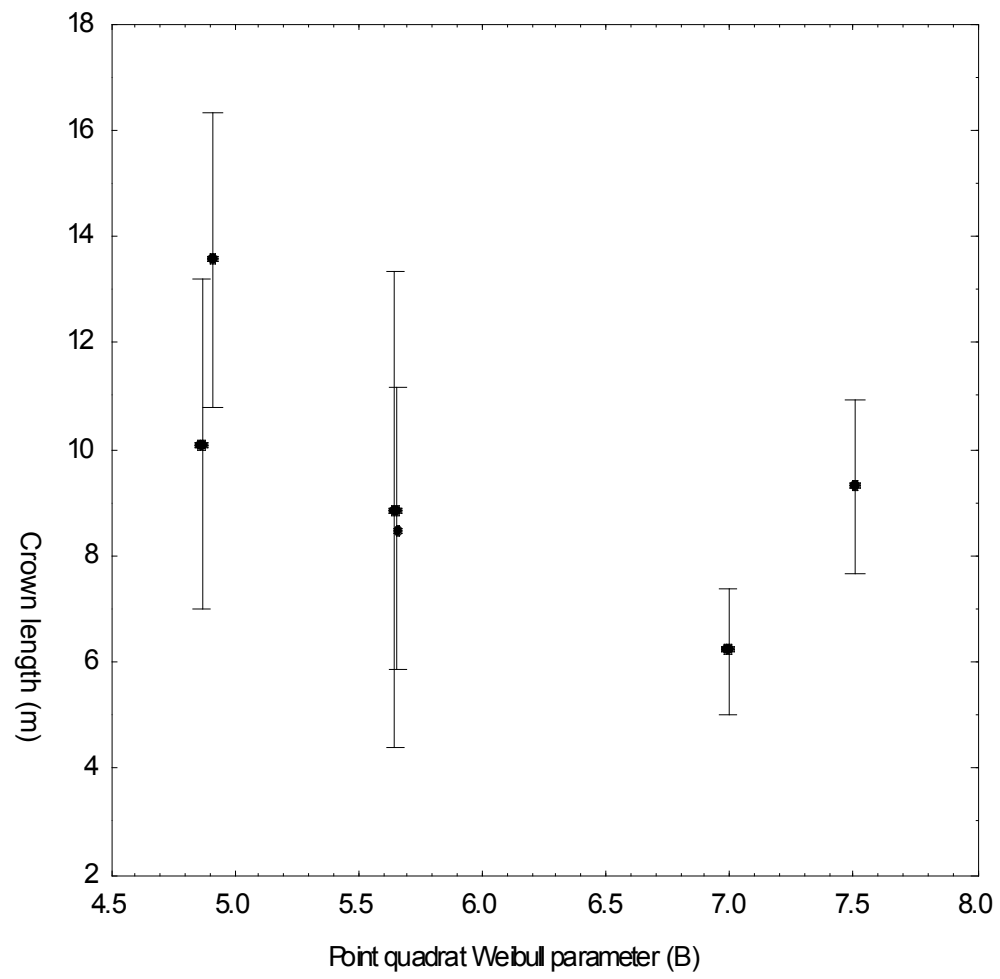


(C)

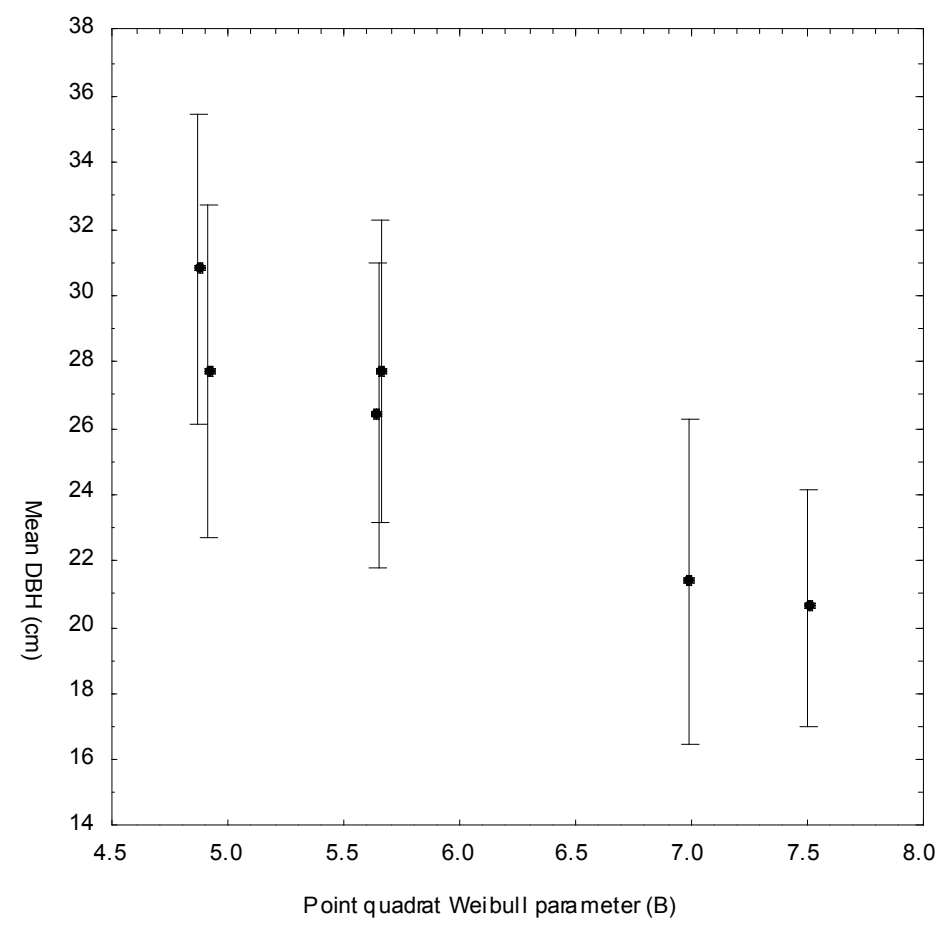

(D)

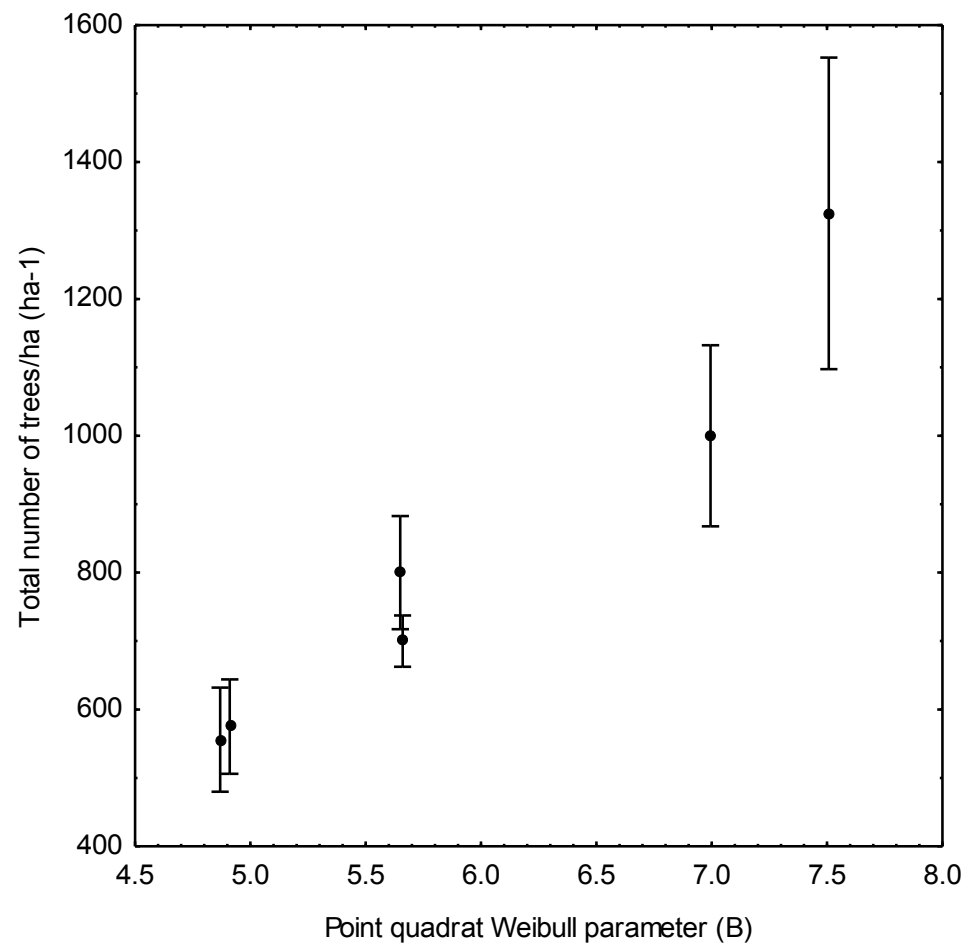

Figure 3 (A)-(D): Relationship between the (a) position of the mid crown depth as a ratio of total height and the Weibull a parameter; (b) Weibull $\beta$ and the average plot crown length, (c) mean plots DBH and 5(d) stocking. All Weibull parameters are distribution fit to point quadrat apparent foliar profile data. 
Similarly, strong relationships were found between the LiDAR derived Weibull $\alpha$ and $\beta$ parameters and the crown height ratio and crown length (Figure $4 a, 4 b)$. The LiDAR derived Weibull $\beta$ parameter was also found to be related to $\mathrm{DBH}$ and stem density (Figure $4 c)\left(r^{2}=0.77\right.$ and $r^{2}=0.65$, both significant at the $p<0.05$ level). The capacity of the Weibull parameters to represent key attributes of mean crown dimension is important, as it provides a mechanism to summarise complex canopy characteristics into simple parameters which can be empirically analysed in relation to various stand characteristics.

(A)

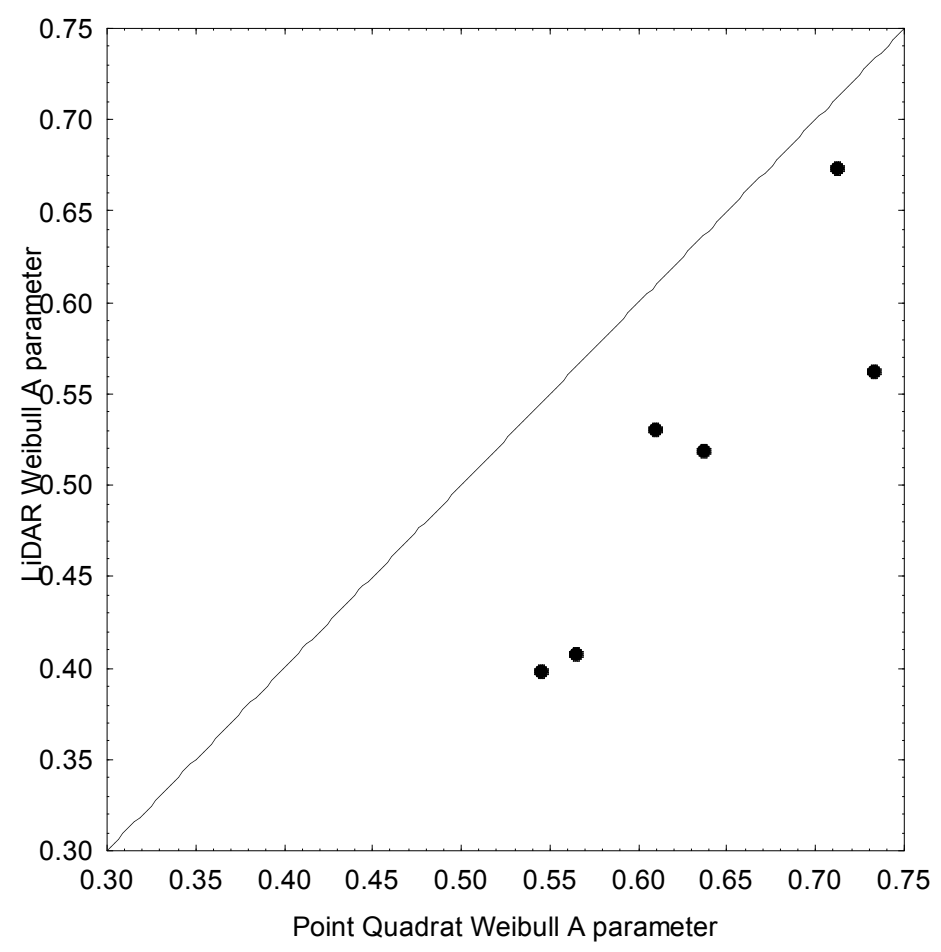


(B)

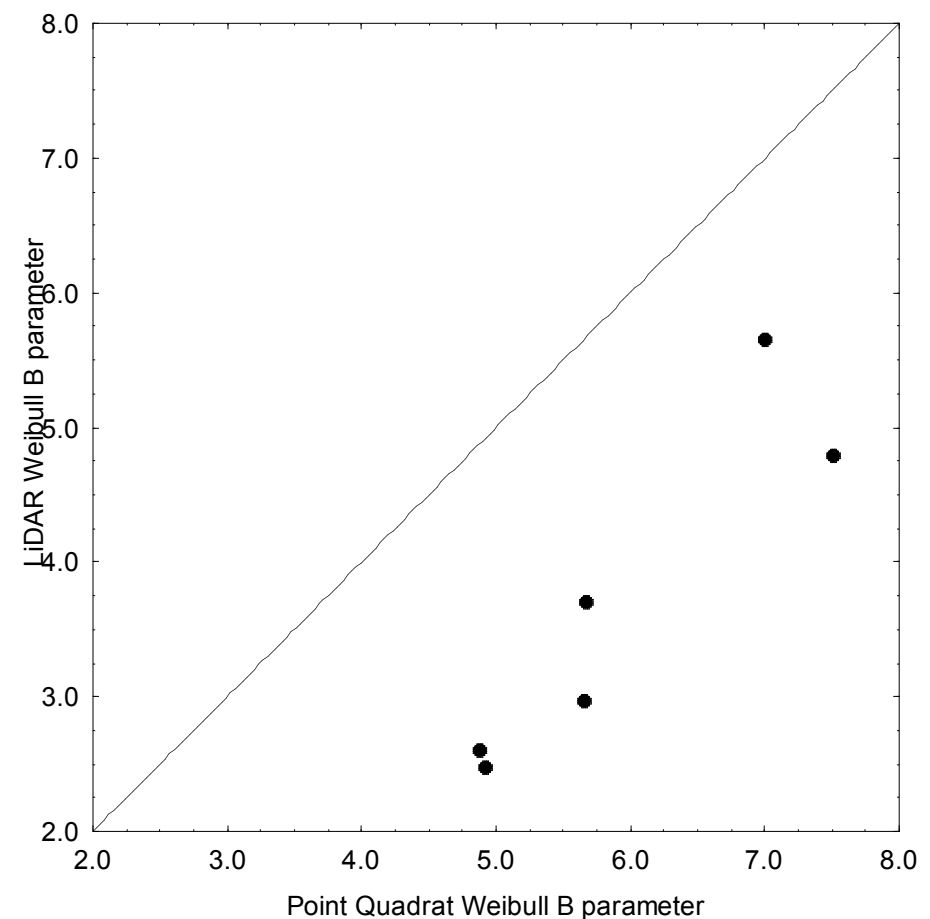


(C)

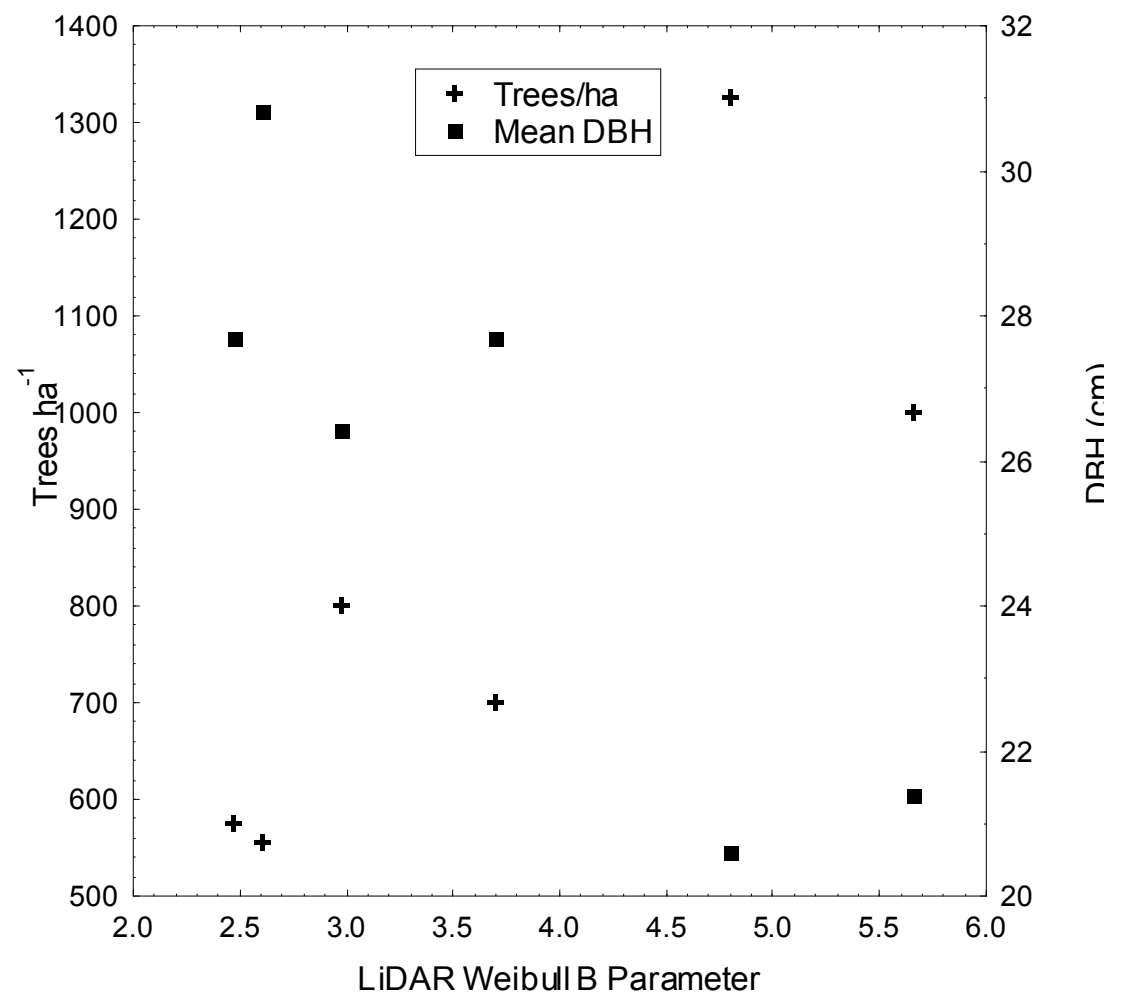

Figure 4 (A)-(C): Relationship between (a) Weibull $\alpha$ and (b) $\beta$ parameters derived from the point quadrat apparent foliage profile data and those derived from the LiDAR returns and the relationship between the LiDAR derived Weibull $\beta$ parameter with (c) DBH and (d) with stocking

Table 3: Correlations between the point quadrat, LiDAR or inventory methods Weibull $\alpha$ and $\beta$ distribution parameters.

\begin{tabular}{llcclll}
\hline Pearsons $(r)$ & $\begin{array}{l}\text { Point } \\
\text { Transect } \\
\end{array}$ & LiDAR $\alpha$ & $\begin{array}{l}\text { Inventor } \\
\text { y data } \alpha\end{array}$ & $\begin{array}{l}\text { Point } \\
\text { Transect } \\
\text { LiDAR } \beta\end{array}$ & $\begin{array}{l}\text { Inventor } \\
\text { y data } \beta\end{array}$ \\
\hline Point & 1 & 0.88 & 0.94 & & \\
Transect $\alpha$ & & & & & \\
LiDAR $\alpha$ & 0.88 & 1 & 0.98 & & \\
\hline
\end{tabular}




\begin{tabular}{|c|c|c|c|c|c|c|}
\hline $\begin{array}{l}\text { Inventory } \\
\text { data } \alpha\end{array}$ & 0.94 & 0.98 & 1 & & & \\
\hline Point & & & & & & \\
\hline Transect $ß$ & & & & 1 & 0.92 & 0.53 \\
\hline LiDAR ß & & & & 0.92 & 1 & 0.47 \\
\hline $\begin{array}{l}\text { Inventory } \\
\text { data } ß\end{array}$ & & & & 0.53 & 0.47 & 1 \\
\hline
\end{tabular}

Apparent Foliage Density Profiles from Point quadrat, Inventory, and LiDAR. For all six stand structural types, the derived field and LiDAR profiles are shown in Figure 5. For stand I, the three fit Weibull foliage profiles correspond well. The maximum field height of $18 \mathrm{~m}$ matches the foliage profiles and the modeled maximum Weibull curve position. The single layer of overstorey vegetation is also well captured by the Weibull distribution. Observational biases can be found in the foliage profiles with the point quadrat method producing a larger proportion of returns from low in the canopy, with the LiDAR returns biased to the top of the canopy. The apparent foliar profiles for stand II and III also show good correspondence between the three methods, and a moderate correspondence between the Weibull curves. All methods detect the taller alder trees, sparsely distributed throughout the stand. However the ability of the Weibull function to capture this sparse distribution of foliage high in the canopy is more limited. The relatively dry, even aged, mixed Douglas fir, hemlock stand IV is well characterized by all methods with very similar Weibull curves produced. Stand V also produced similar Weibull coefficients for all datasets, except that the point quadrat method more clearly detects two overstorey layers and the LiDAR peak foliar density is about $10 \mathrm{~m}$ higher $(28 \mathrm{~m})$ than the other two methods. In the final plot $(\mathrm{VI})$ with mature Douglas fir and larger hemlock and cedar trees, there is marked vertical complexity with a well-defined overstorey greater than $25 \mathrm{~m}$ and another mid-storey layer at $15 \mathrm{~m}$. As a result, the foliage profiles from the different methods vary, and a single Weibull distribution applied to the profile is inadequate to fully capture the full structure as 
estimated from the inventory data. In the case of the point quadrat and the LiDAR observations of the canopy, the Weibull is a good fit. However, it is clear they are only representing select portions of the overall stand. In these situations, an approach such as that used by Zimble et al. (2003) which classifies stands based on height variation may be possible to segregate the canopy into two layers and fit separate distributions to fully describe the multi-layered structure. 

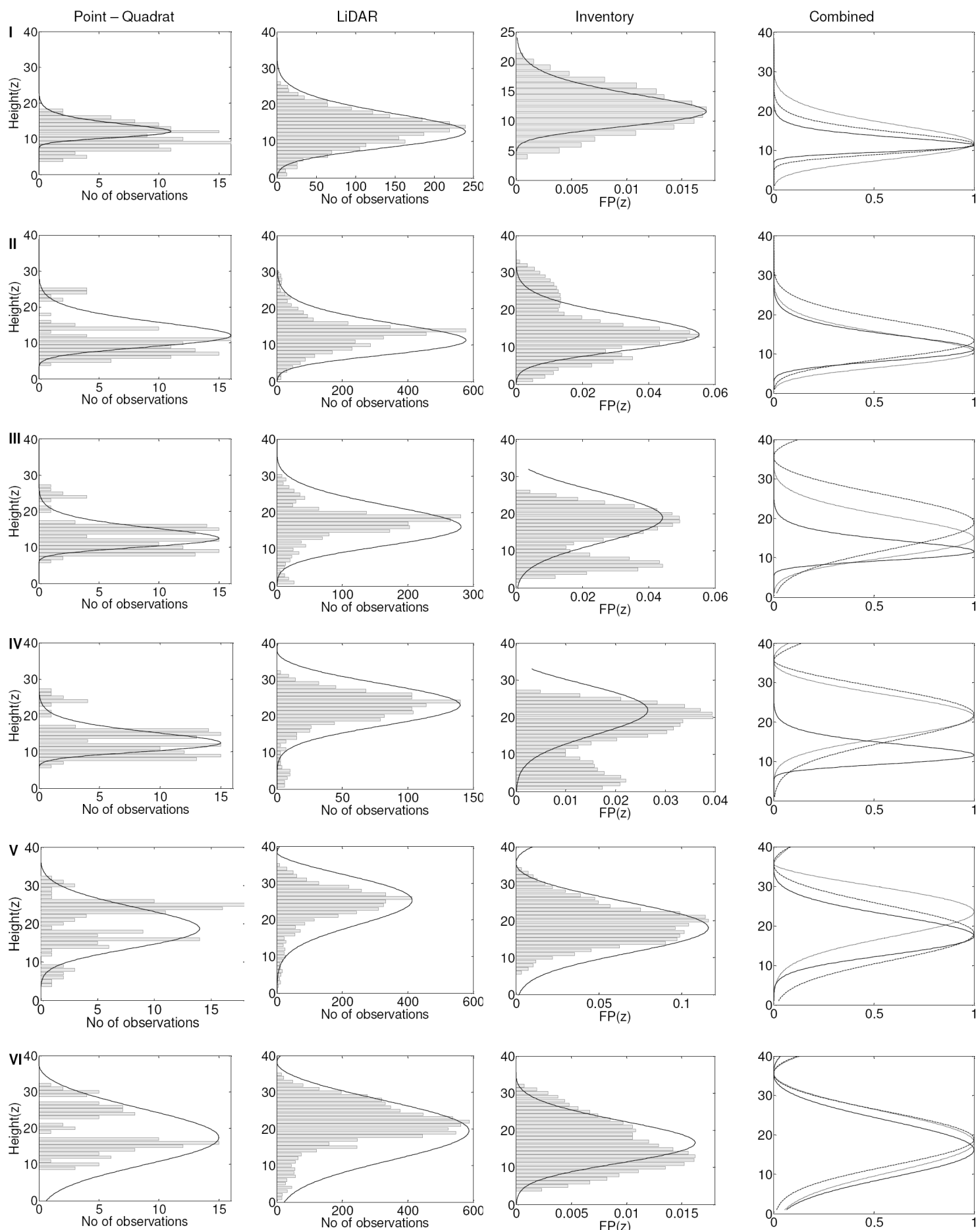

Figure 5: Apparent foliage profiles and Weibull distributions for the six stands (I - VI as in Table 1) derived from the (Column 1) point quadrat, (Column 2) LiDAR returns, (Column 3) modelled inventory data, and (Column 4) combined Weibull distributions for all three methods (dash line - point quadrat, dotted line - LiDAR, solid line - inventory.) 


\subsection{Canopy Volume Profiles}

The canopy volume profile estimates clearly demonstrate the horizontal variation in the spatial arrangement of elements within the vertical forest canopy (Figure 6). The canopy volume profile patterns are similar to those described by Lefsky et al. (1999) which provides confidence that the adapted method is valid for discrete small footprint LiDAR. The relatively homogenous Douglas fir stand in plot I (mean height $18 \mathrm{~m}$, mean DBH $20 \mathrm{~cm})$, has the majority of its canopy volume filled $(70 \%)$ with both oligophotic and euphotic hits (Table 2). This stand also had the smallest closed gap volume of all stands. The proportion of filled volume generally decreases at later structural stages to around $60 \%$ indicating a thinning of the stand and canopy, with the proportion of the euphotic zone decreasing to approaching $30 \%$ of the total filled volume. In more structurally complex stands (e.g. IV and VI), especially when containing larger trees, the filled volume decreases to $40 \%$ of the canopy and the closed volume or gap increases to a maximum. In the less complex stands there is a general horizontal arrangement of canopy volume profile layers, however in the mixed, and mostly older stands each canopy volume profile zone occurs in most layers indicating large vertical complexity in the canopy structure. The total amount of open gap was highest in the mixed alder, Douglas fir stands (II and III) as it driven by the subplot height differences within the 20 
$x 20 m$ window.
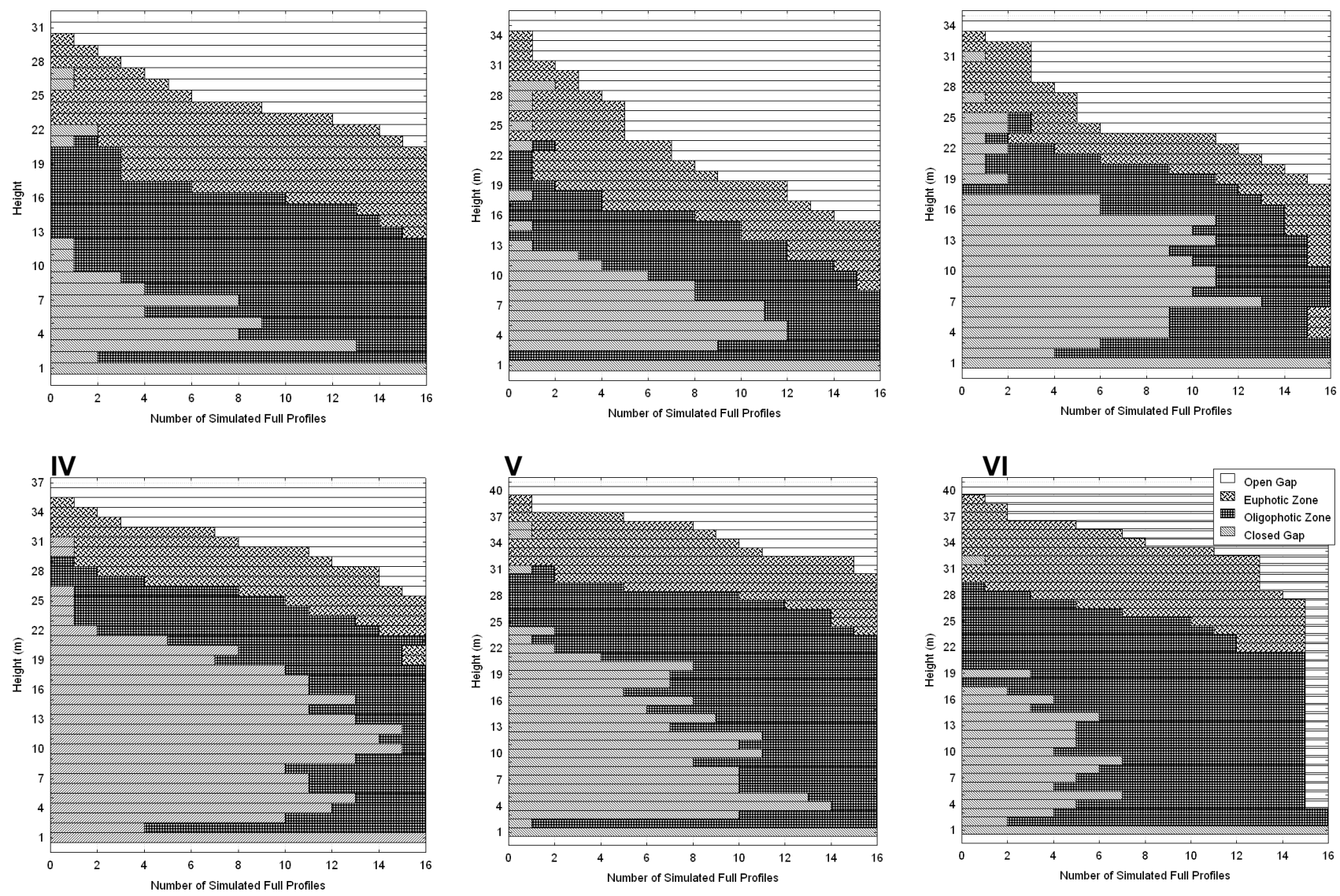

Figure 6: Canopy volume profile estimates for each of the six stands (1 - VI Table 1) using modified methodology of Lefsky et al. (1999).

\subsection{Canopy volume profile variables with stand attributes}

LiDAR derived canopy volume profile were found to be correlated with one or more stand attributes including crown volume, stem density and basal area (Table 4) with a number of the correlations similar to those found by Lefsky et al. (1999) (shown as highlighted cells). As expected, overall crown volume was found to be correlated to the volume of the canopy volume profile oligophotic and euphotic zones. Logically, LAl is positively correlated to the filled canopy volume. Lefsky et al. (1999) also used canopy volume profile variables to develop a series of multiple regression equations for stand attributes, and found the predictions highly accurate and without an asymptotic tendency indicating robustness even at high levels of above ground biomass. 
Table 4: Correlations ( $r$ ) between canopy volume profile variables and field-measured stand attributes at the six sites.

\begin{tabular}{|c|c|c|c|c|c|}
\hline & $\begin{array}{l}\text { Closed } \\
\text { Gap }\end{array}$ & $\begin{array}{l}\text { Oligiophotic } \\
\text { Zone }\end{array}$ & $\begin{array}{l}\text { Euphotic } \\
\text { Zone }\end{array}$ & $\begin{array}{l}\text { Open } \\
\text { Gap }\end{array}$ & $\begin{array}{l}\text { Filled } \\
\text { Canopy } \\
\text { Volume }\end{array}$ \\
\hline Mean Height $(\mathrm{m})$ & & & & & 0.92 \\
\hline $\begin{array}{l}\text { Stand Volume }\left(\mathrm{m}^{3}\right. \\
\left.\mathrm{ha}^{-1}\right)\end{array}$ & & & & & 0.87 \\
\hline $\begin{array}{l}\text { Crown volume }\left(\mathrm{m}^{3}\right. \\
\left.\mathrm{ha}^{-1}\right)\end{array}$ & & -0.84 & -0.87 & & \\
\hline LAI & 0.81 & & & & 0.70 \\
\hline $\begin{array}{l}\text { Total basal area }\left(\mathrm{m}^{2}\right. \\
\left.\mathrm{ha}^{-1}\right)\end{array}$ & & & & & 0.70 \\
\hline $\begin{array}{l}\text { Basal area Douglas } \\
\text { Fir }\left(\mathrm{m}^{2} \mathrm{ha}^{-1}\right)\end{array}$ & & & & 0.81 & \\
\hline $\begin{array}{l}\text { Basal area Hemlock } \\
\left(\mathrm{m}^{2} \mathrm{ha}^{-1}\right)\end{array}$ & & & & 0.60 & \\
\hline
\end{tabular}

\section{DISCUSSION AND CONCLUSION}

Characterizing vertical and horizontal forest structure is critical for supporting management activities, such as planning silvicultural treatments or habitat assessment for rare, endangered, and threatened species. In this paper we present three methods of assessing and charactering forest structure using LiDAR and field-based inventory and point-quadrat methods, fitting the Weibull distribution to apparent foliar profiles and the use of the canopy volume profile model. 
Errors of up to $3 \mathrm{~m}$ in height can be found in many LiDAR studies and are within the measurement error of most field estimates (Coops et al. 2004b). LiDAR results typically underestimate the plot heights observed on the ground (Næsset 1997, Magnussen and Boudewyn 1998, Lovell et al. 2003, Coops et al. 2004b, Yu et al. 2004) due to the sampling nature of terrain LiDAR and the low probability that a LiDAR beam consistently hits the apex of each crown (St-Onge et al. 2003). Increasing the LiDAR hit density, by either flying at a lower altitude or at a slower speed, or by aggregating the data from multiple overpasses, will reduce this underestimation. For example, Hyyppä et al. (2000) increased sampling rate from 9 to $24 \mathrm{hits} / \mathrm{m}^{2}$ and found a reduction in the error and bias in tree height estimation. In addition positional errors associated with both the plot placement using GPS (potentially up to $1-2 \mathrm{~m}$ ) as well as possible locational errors with the LiDAR of up to $1 \mathrm{~m}$ can both contribute to the lack of a perfect fit between the observed maximum height and the LiDAR observed heights. Finally, field measurement error, especially in dense forest canopies, due to difficulties in identifying the top of tall tree crowns can also result in a field-based errors of up to $2 \mathrm{~m}$ in tall tree crowns.

\subsection{Weibull Apparent Foliar Profile Distribution Parameters and Stand Structure}

\section{Attributes}

Previous research has demonstrated that the Weibull distribution can be applied to characterize foliage biomass at a range of scales such as the branch, tree and stand level. For example, Xu and Harrington (1998) found that for trees of greater dominance, branch foliage biomass was more evenly distributed across the branch length than for subdominants trees. In addition, for increasing crown ratios, foliage biomass shifted from the inner to the outer crown. In the vertical dimension, trees of greater dominance produced a more uniform foliage distribution compared to sub-dominant crowns. The Weibull parameters discussed here can be interpreted in a similar way with changes in the distribution of LiDAR returns being associated with varying patterns of biomass distribution within the crown. The correlations between the position of the mid-crown depth as a ratio of total height and the Weibull $\alpha$ parameter and $\beta$ with average crown 
length are consistent between the field data and the point quadrat foliage profile. This is also true for the relationship between the field-based methods and the LiDAR estimated Weibull parameters. This indicates that LiDAR data can be used, not only to derive standard forest inventory information, but also to evaluate overall canopy structure. This is important in understanding the role of individual tree competition (Biging and Dobbertin 1992) as well as an assessment of wildlife habitat or abundance (Morrison et al. 1987).

The Weibull distribution can be used to represent most of the stand structural types examined in this study. However a simple distribution function has a limited capacity to model a multi-layered stand, such as the mature Douglas fir stand with large hemlock and cedar trees (stand IV) shown in Figure 5. A simple Weibull distribution in this case can be modeled to fit either the understorey or the overstorey components. However, it is beyond this single distribution to match the combined bi-modal form. For a complete description of multi-storey stands, a multi curve fitting approach can be applied, which effectively stratifies the vertical canopy into key layers and then fits the Weibull distribution to each layer separately. Figure 7 demonstrates the fitting of two Weibull curves, for Stand IV, one for the understorey and another for the overstorey layer.
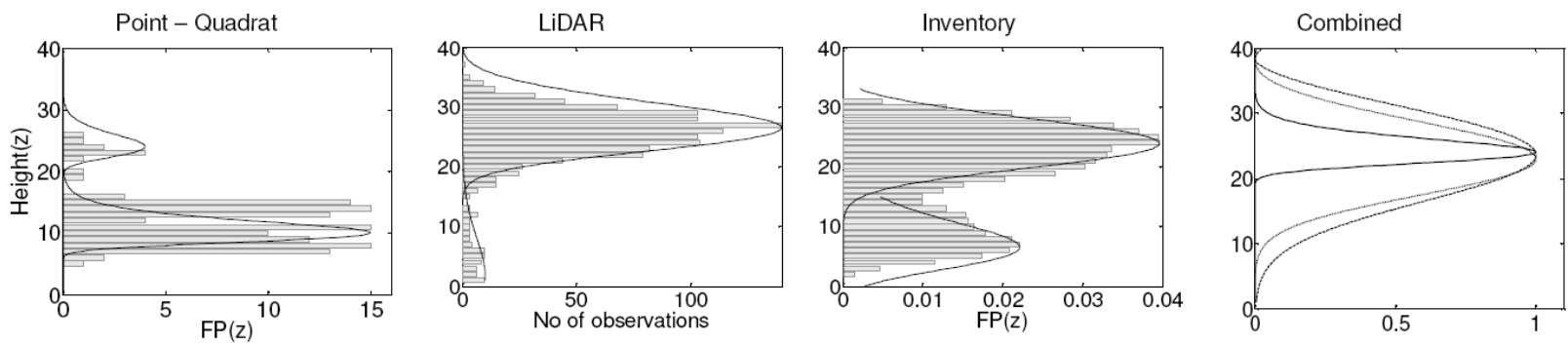

Figure 7: Fitting of apparent foliage profiles for stand VI using two combined Weibull distribution functions for mid- and overstorey.

The Weibull $\alpha$ and $\beta$ parameters show a significant correlation with several important crown attributes. The relationship between the Weibull a parameter and crown depth indicates that traditional measures such as height to crown, and height to live crown can also be derived over the broad spatial coverage available through airborne LiDAR observations. The significant correlations between the Weibull $\beta$ parameter with mean crown length indicate the overall shape of the crown has a predictable effect on the 
LiDAR returns. Furthermore, the stocking, and mean DBH of the stand are also related to crown size (Gering 1995) resulting in correlations between the Weibull $\beta$ parameter and these attributes, indicating that indirect estimation of these parameters may be possible.

\subsection{Canopy Volume Profiles and Stand Structure}

The results also indicate that the canopy volume profile methodology developed by Lefksy et al. (1999) for large footprint full waveform LiDAR observations appear to be transferable to small footprint, discrete, return LiDAR observations. Changes in the proportion of different canopy volume types (such as closed gap, open gap, and filled canopy) vary in a regular way with respect to age as described by Lefksy et al. (1999). The overall canopy surface structure is well characterized by the total amount of the "open gap" canopy volume profile class with dense, shorter stands showing an even upper canopy surface, while the mixed, more variable crown structures, have a significantly higher amount of open gaps indicative of increased total canopy surface (possibly self thinning or management).

The total amount of closed gaps within the canopy is higher for the planted, mature stands than for the naturally regenerating stands. The largest amount of empty space is observed within the monoculture of stand $V$ where dense stocking of similar aged trees produces dense canopies with little vegetation beneath the crowns (Lefksy et al. 1999). The amount of euphotic and oligophotic crown volume provides an indication of density of the upper crown layer, as it is related to the penetration rate of the LiDAR beams through the canopy. Laser shots will be able to penetrate more open stands better than closed ones. Thus, an open canopy structure will also return more shots from the lower region of the canopy and consequently result in a bigger volume for the "euphotic" zone. In the same way, crown length is also strongly related to the total filled volume (sum of the euphotic zone, oligophotic zone and open gap) which is, in essence, a 3dimensional expression for the mean crown depth per unit area. A similarly strong relationship exists between the total filled volume and the total crown volume and the arithmetic mean tree height per plot. Whilst the limited number of observations in this 
study precludes the development of rigorous regressions models, the correlations of canopy volume variables to at least one of the stand structural attributes suggest with more data similar models could be developed for these forests.

\section{ACKNOWLEDGEMENTS}

We thank David Seeman, Bob Ferris (Canadian Forest Service) and Rachelle Lalonde (UBC) for field assistance. Prof. Andy Black and staff allowed access to the FLUXNET Canada site. We thank forest companies Timberwest and Weyerhaeuser for providing access to their forest inventories of the area and access to their private lands. We acknowledge staff from the CSIRO Canopy LiDAR project, in particular Dr Jenny Lovell, for assistance with the development of the in-house software used for the analysis of the LiDAR data. The LiDAR data was acquired by Benoit St-Onge as part of an ongoing collaborative project with funds provided by NSERC and BIOCAP. Components of this research were also funded by a NSERC Discovery grant to Coops and DAAD postgraduate scholarship to Hilker. Preparation of the combined forest inventory and disturbance coverages was done partially through Action Plan 2000 and FLUXNET CCAF funding to T. Trofymow. Finally, we are grateful to the two anonymous reviewers who provided editorial suggestions. 


\section{REFERENCES:}

Aber JD (1979a) Foliage-height profiles and succession in northern hardwood forests. Ecology 60:18-23

Aber JD (1979b) A method for measuring foliage-height profiles in broad-leaved forests. Journal of Ecology 67:35-40

Axelsson P (1999) Processing of laser scanner data-algorithms and applications. ISPRS Journal of Photogrammetry and Remote Sensing 54:138- 147

Bailey RL, Dell TR (1973) Quantifying diameter distributions with the Weibull distribution. Forest Science 19:97-104

Barclay HJ, Goodman D (2000) Conversion of total to projected leaf area index in conifers. Canadian Journal of Botany 78:447-454

Biging GS, Dobbertin M (1992) A comparison of distance dependent competition measures for height and basal area growth of individual conifer trees. Forest Science 38:695-720

Blair JB, Rabine DL, Hofton MA (1999) The laser vegetation imaging system; a medium-altitude digitisation-only airborne laser altimeter for mapping vegetation and topography. ISPRS Journal of Photogrammetry and Remote Sensing 54: $115-122$

Brokaw N, Lent R (1999) Vertical structure. In: Hunter M (eds) Maintaining Biodiversity in Forest Ecosystems. Cambridge University Press Boston USA 373-399

Chasan J, Baldocchi D, Huston M (1991) A comparison of direct and indirect methods for estimating forest canopy leaf area. Agricultural and Forest Meteorology 57:107-128.

Chen JM, Paw UKT, Ustin SL, Suchanek TH, Bond BJ, Brosofske KD, Falk M (2004) Net ecosystem exchanges of carbon water and energy in young and old-growth Douglas-fir forests. Ecosystems 7:534-44

Chen JM, Rich PM, Gower TS, Norman JM, Plummer S (1997) Leaf area index of boreal forests: theory techniques and measurements. Journal of Geophysical Research 102(D24):29429-29444

Coops NC, Smith ML, Jacobson K, Martin M, Ollinger S (2004a) Estimation of Leaf Area Index using three techniques in a mature native eucalypt canopy. Austral Ecology 29: 332-341

Coops NC, Wulder MA, Culvenor DC, St-Onge B (2004b) Comparison of forest attributes extracted from fine spatial resolution multi-spectral and LiDAR data Canadian Journal of Remote Sensing 30: 855-866

Cohen WB, Spies TA (1992) Estimating structural attributes of Douglas Fir/Western Hemlock forest stands from Landsat and SPOT imagery. Remote Sensing of Environment 41:1-17 
Demarchi, DA (1996) An Introduction to the Ecoregions of British Columbia Victoria: BC Ministry of Environment Lands and Parks http://wwwenvgovbcca/rib/wis/eco

Franklin JF, Spies TA, Van Pelt R, Carey A, Thornburgh D, Burg DR, Lindenmayer D (2002) Disturbances and the structural development of natural forest ecosystems with some implications for silviculture. Forest Ecology and Management 155:399-423

Gering LR (1995) The relationship of diameter at breast height and crown diameter for four species groups in Hardin County Tennessee. Southern Journal of Applied Forestry 19:177-181

Gillespie AR, Allen HL, Vose JM (1994) Amount and vertical distribution of foliage of young loblolly pine trees as affected by canopy position and silvicultural treatment. Canadian Journal of Forest Research 24: 1337-1344

Goodwin G (1937) Regeneration Study on the logged-off lands of the Comox Logging and Railway Company Oyster River Forest Survey No R 72 Survey file No 0124780 BC Forest Service 39p and Map

Green RN, Klinka K (1994) A Field Guide to Site Identification and Interpretation for the Vancouver Forest Region: Land Management Handbook \# 28 Victoria: Province of British Columbia

Gower ST, Norman JM (1991) Rapid estimation of leaf area index in conifer and broadleaf plantations Ecology 72:1896-1900

Harding DJ, Lefsky MA, Parker GG, Blair JB (2001) Laser altimeter canopy height profiles method and validation for closed-canopy broadleaf forests. Remote Sensing of Environment 76: 283-297

Hall SA, Burke IC, Box DO, Kaufmann MR, Stoker JM (2005) Estimating stand structure using discrete-return lidar: an example from low density fire prone ponderosa pine forests. Forest Ecology and Management 208:189-209

Harmon ME, Franklin JF, Swanson FJ, Sollins P, Gregory SV, Lattin JD, Anderson NH, Cline SP, Aumen NG, Sedell JR, Lienkaemper GW, Cromack K Jr, Cummins KW (1986) Ecology of coarse woody debris in temperate ecosystems. In Advances in ecological research (eds) MacFadyen A, Ford ED Orlando Florida: Academic Press Inc 15:133-302

Hutchinson MF (1989) A new procedure for gridding elevation and stream line data with automatic removal of spurious pits. Journal of Hydrology 106:211-232

Hyyppä J, Hyyppä H, Inkinen M, Engdahl M, Linko S, Zhu Y-H (2000) Accuracy comparison of various remote sensing data sources in the retrieval of forest stand attributes Forest Ecology and Management 128: 109-120

Kershaw JA Jr, Maguire DA (1995) Crown structure in western hemlock Douglas-fir and grand fir in western Washington: trends in branch-level mass and leaf area. Canadian Journal of Forest Research 25: 1897-1912 
Kraus K, Pfeifer N (1999) Determination of terrain models in wooded areas with airborne scanner data. ISPRS Journal of Photogrammetry and Remote Sensing. $54: 193-203$

Lim K, Treitz P, Wulder MA, St-Onge B, Flood M (2003) LiDAR remote sensing of forest structure Progress in Physical Geography 27:88-106

Lefsky MA Harding D Cohen W B Parker G and Shugart H H (1998) Surface LiDAR Remote Sensing of Basal Area and Biomass in Deciduous Forests of Eastern Maryland USA Remote Sensing of Environment 67:83-98

Lefsky MA, Cohen WB, Acker SA, Parker GG, Spies TA, Harding D (1999) LiDAR Remote Sensing of the Canopy Structure and Biophysical Properties of DouglasFir Western Hemlock Forests. Remote Sensing of Environment 70: 339-361

Lefsky MA, Hudak AT, Cohen WB, Acker SA (2005) Geographic variability in lidar predictions of forest stand structure in the Pacific Northwest. Remote Sensing of Environment 95:532-548

Lovell JL, Jupp DLB, Culvenor DS, Coops NC (2003) Using airborne and ground-based ranging lidar to measure canopy structure in Australian forests. Canadian Journal of Remote Sensing 29:1-16

Magnussen S, Boudewyn P (1998) Derivations of stand heights from airborne laser scanner data with canopy-based quantile estimators. Canadian Journal of Forest Research 28:1016-1031

Magnussen S, Eggermont P, LaRiccia V (1999) Recovering tree heights from airborne laser scanner data. Forest Science 45:407-422

MacKinnon A (2003) West-coast temperate old-growth forests Forestry Chronicle 79:475-484

MacArthur RH, Horn HS (1969) Foliage profile by vertical measurements. Ecology 50:802-804

Means JE, Acker SA, Harding DJ, Blair JB, Lefsky MA, Cohen WB, Harmon ME, McKee A (1999) Use of large-footprint scanning airborne lidar to estimate forest stand characteristics in the western Cascades of Oregon. Remote Sensing of Environment 67: 298-308.

Morrison ML, Timosse IM, With KA (1987) Development and testing of linear regression models predicting bird-habitat relationships. Journal of Wildlife Management 51:247- 253

Næsset E (1997) Determination of mean tree height of forest stands using airborne laser scanner data. ISPRS Journal of Photogrammetry and Remote Sensing 52 : 49-56

Næsset E, Økland T (2002) Estimating tree height and tree crown properties using airborne scanning laser in a boreal nature reserve. Remote Sensing of Environment 79: 105-115 
Næsset E (2002) Predicting forest stand characteristics with airborne scanning laser using a practical two-stage procedure with field data. Remote Sensing of Environment 80:88-99

Næsset E, Gobakken T, Holmgren J, Hyyppä H, Hyypää J, Maltamo M, Nilsson M, Olsson H, Persson Å. Söderman U. (2004) Laser scanning of forest resources: the Nordic experience. Scandinavian Journal of Forest Resources 19:482-499.

Ni-Meister W Jupp D \& Dubayah R (2001) Modeling LiDAR waveforms in heterogeneous and discrete canopies IEEE Transactions on Geoscience and Remote Sensing 39 1943-1957

Persson A, Holmgren H, Söderman U (2002) Detecting and measuring individual trees using an airborne Laser scanner. Photogrammetric Engineering and Remote Sensing 68:925-932

Parker GG, Harmon ME, Lefsky MA, Chen JQ, Van Pelt R, Weis SB, Thomas SC, Winner WE, Shaw DC, Franklin JF (2004) Three-Dimensional Structure of an Old-Growth Pseudotsuga-Tsuga Canopy and Its Implications for Radiation Balance Microclimate and Gas Exchange. Ecosystems 7:440-453

Pojar J, MacKinnon A (1994) Plants of coastal British Columbia including Washington Oregon and Alaska Lonepine Press Vancouver BC

Pojar J, Klinka K, Demarchi DA (1991)Coastal Western Hemlock Zone. In Meidinger D, Pojar J (eds) Ecosystems of British Columbia. BC Special Report Series No 6 Victoria: BC Ministry of Forests pp 95-111

Radtke P, Bolstad P (2001) Laser point-quadrant sampling for estimating foliage-height profiles in broad-leaved forests. Canadian Journal of Forest Research 31 410418

Riano D, Meier E, Allgower B, Chuvieco E, Ustin SL (2003) Modeling airborne laser scanning data for the spatial generation of critical forest parameters in fire behaviour modelling. Remote Sensing of Environment 86:177-186

Richards, PW (1983), The three dimensional structure of tropical rain forest. In Tropical Rain Forest: Ecology and Management (S. L. Sutton, T. C. Whitmore, and A. C. Chadwick, Eds.), Blackwell, Oxford, pp. 3-10.

Rhoads AG, Hamburg SP, Fahey TJ, Siccama TG, Kobe R (2004) Comparing direct and indirect methods of assessing canopy structure in a northern hardwood forest. Canadian Journal of Forest Research. 34: 584-591

St Onge B, Treitz P, Wulder MA (2003) Tree and Canopy Height Estimation with Scanning Lidar In Wulder MA, Franklin SE (eds) Remote Sensing of Forest Environments: Concepts and Case Studies. Kluwar Academic Publishers Boston pp 489-509

Seischab FK, Bernard JM, Eberle MD (1993) Glaze storm damage to western New York forest communities. Bulletin of the Torrey Botanical Club 120:64-72 
Schenk T, Seo S, Csatho B (2001) Accuracy study of airborne LASER scanning data with photogrammetry. International Archives of Photogrammetry and Remote Sensing XXXIV-3/W4:113-118

Smith ML, Martin ME (2001) A plot-based method for rapid estimation of forest canopy chemistry Canadian Journal of Forest Research 31:549-55

Taylor S (2002) British Columbia Natural Disturbance Database http://wwwpfccfsnrcangcca/fires/disturbance/index_ehtml

Whitney HE, Johnson WC (1984) Ice storms and forest succession in southwestern Virginia Bull Torrey Botanical Society 111: 429-437

Walker J Hopkins MS (1990) Vegetation In: McDonald RC Isbell RF Speight JG Walker J, Hopkins MS (eds) Australian Soil and Land Survey: Field Handbook Second Edition Inkata Press Melbourne

Waring RH, Law B, Goulden ML, Bassow SL, McCreight RW, Wofsy SC, Bazzaz FA (1995) Scaling gross ecosystem production at Harvard Forest with remote sensing: a comparision of estimates from a constrained quantum-use efficiency model and eddy correlation. Plant Cell and Environment 18:1201-1213

Warren Wilson J (1960) Inclined point quadrats New Phytologist. 59:1-8

Warren Wilson J (1963) Estimation of foliage denseness and foliage angle by inclined point quadrats. Australian Journal of Botany 11:95-105

Van Pelt R and N M Nadkarni 2004 Horizontal and vertical distribution of canopy structural elements of Pseudotsuga menziesii forests in the Pacific Northwest Forest Science 50:326-341

Vose JM (1988) Patterns of leaf area distribution within crowns of nitrogen- and phosphorus-fertilized loblolly pine trees. Forest Science 34: 564-573

Xu M, Harrington TB (1998) Foliage biomass distribution of loblolly pine as affected by tree dominance crown size and stand characteristics. Canadian Journal of Forest Research 28:887-892

Yu X, Hyypa J, Kaartinen H, Maltamo M (2004) Automatic detection of harvested trees and determination of forest growth using airborne laser scanning. Remote Sensing of Environment 90:451-462

Zimble DA, Evans DL, Carlson GC, Parker RC, Grado SC, Gerand PD (2003) Characterizing vertical forest structure using small-footprint airborne LiDAR. Remote Sensing of Environment 87: 171-182 